IRA-International Journal of Management \& Social Sciences

ISSN 2455-2267; Vol.08, Issue 01 (July 2017)

Pg. no. 103-117

Institute of Research Advances

http://research-advances.org/index.php/RAJMSS

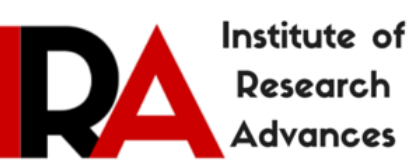

\title{
The Role of Packing on Buying Behaviour of Rural Consumers with Special Reference to FMCG
}

Dr. Sathyanarayana S

Associate Professor, MPBIM, Bangalore, India.

Dr. B. H. Suresh

Professor, University of Mysore, Mysore, India.

Type of Review: Peer Reviewed.

DOI: http://dx.doi.org/10.21013/jmss.v8.n1.p12

\section{How to cite this paper:}

Sathyanarayana, S., \& Suresh, B. (2017). The Role of Packing on Buying Behaviour of Rural Consumers with Special Reference to FMCG. IRA-International Journal of Management \& Social Sciences (ISSN 24552267), 8(1), 103-117. doi:http://dx.doi.org/10.21013/jmss.v8.n1.p12

(C) Institute of Research Advances.

(cc) Br-No

This work is licensed under a Creative Commons Attribution-Non Commercial 4.0 International License subject to proper citation to the publication source of the work.

Disclaimer: The scholarly papers as reviewed and published by the Institute of Research Advances (IRA) are the views and opinions of their respective authors and are not the views or opinions of the IRA. The IRA disclaims of any harm or loss caused due to the published content to any party.

Institute of Research Advances is an institutional publisher member of Publishers Inter Linking Association Inc. (PILA-CrossRef), USA. The institute is an institutional signatory to the Budapest Open Access Initiative, Hungary advocating the open access of scientific and scholarly knowledge. The Institute is a registered content provider under Open Access Initiative Protocol for Metadata Harvesting (OAI-PMH).

The journal is indexed \& included in WorldCat Discovery Service (USA), CrossRef Metadata Search (USA), WorldCat (USA), OCLC (USA), Open J-Gate (India), EZB (Germany) Scilit (Switzerland), Airiti (China), Bielefeld Academic Search Engine (BASE) of Bielefeld University, Germany, PKP Index of Simon Fraser University, Canada. 


\begin{abstract}
Indian rural market with its enormous size and demand base offers great opportunities to marketers. However, there are many serious challenges that FMCG manufactures face in tackling rural markets, viz., the scattered nature of rural markets, their small size, remoteness, poor connectivity and tremendous heterogeneity, low level of literacy, too many languages and dialects, cultural diversities, inadequate banking facilities, acute dependence on the monsoon; seasonal demand, and media darkness are some serious limitations. However, the issue of packing is very crucial when it comes to marketing of brands in rural areas as the brand recognition in rural areas generally through its colours, logos, shape and size. Therefore, the current study has been undertaken with an intention to understand the role of packing in rural markets. In order to realize the stated objectives the researcher constructed a structured questionnaire has been constructed and pre tested and administered on 1,600 rural respondents spread across 200 villages in the state of Karnataka. The study revealed that packing make a significant role while buying FMCG. There is a significant difference in the opinion of rural consumer respondents on importance attributed to packing while purchasing FMCG as perceived by rural consumer respondents. There is a significant influence of annual house hold income of the rural consumer respondents on the level of importance attributed to packing while buying FMCG. Majority of the rural consumer respondents preferred sachets while buying FMCG. There is a significant difference in the packing size preference of the rural consumer respondents while purchasing products. There is a significant influence of the annual house hold income of the rural consumers on kind of packing preference. Majority of the rural respondents recognize brands through reading, colours, scanning of logos/pictures/trademarks and through packing style of the products. Based on the analysis of the study a brief summary of findings have been made and a meaningful conclusion has been drawn. Finally the results have been compared with the possible evidence.
\end{abstract}

Key words: Emotional Surplus Identity, Brand, Packing, Rural consumers, FMCG, symbols and $\log$ os.

\title{
I. INTRODUCTION
}

The attraction towards the Indian rural markets is primarily due to the colossal size of the varied demands of the huge customer base in rural India. Unfortunately, for most of the marketers, rural begins where their controllable, distribution and media reach ends. They have treated rural markets as adjuncts to their urban strongholds and rural consumers as a homogeneous mass without segmenting them into target markets and positioning brands appropriately (Thakker \& Bhagag).Most of them pay lip service to rural marketing and run only on van operations in village's squares and weekly markets, cinema commercials and a few wall paintings.

The Indian rural market is very vast in size and in demand base. It offers great opportunities to marketers. However, the biggest mistake a FMCG marketer can make while entering the rural market is to treat it as an extension to the existing urban market. Almost all the rural marketing strategies have enjoyed an urban lifestyle and can more easily connect to the urban mindset. But the whole issue is that there is a vast difference in the lifestyle of the rural and urban consumers (Das and Sen 1991); (Richa Mishra 2003); (Kamath and Moorthy 2003) and (2001). The difference is not only between urban and rural but also with in the rural areas. Banerjee (2002) suggests that the marketers should have two different mindsets while offering products or services - one is an urban mindset and other being rural mindset and marketers should offer appropriate goods and services according to these two divergent mindsets.

Product packing decision is a central issue in rural marketing. As all brands or products are not equally liked by a rural consumer and he or she selects his or her brand after a careful analysis of a number of factors associated with it. The size of the pack plays a vital role while marketing FMCG to the rural consumers. The major factors which drive the selection a particular brand by rural consumers may be on the basis of the affordability, brand image, personal usage experience, opinion of the retailers, storability, contents display, logo, colour etc. However, the issue of packing is very crucial when it comes to marketing of brands in rural areas as the brand recognition in rural areas generally through its colours, logos, shape and size. A brand name in the rural area facilitates easy brand recall and in drawing any colours, visual or numeric association. Emotional Surplus Identity (ESI)) is a concept that uses the shape, color, and content of a package to differentiate a brand 
in the eye of a consumer (Sen \& Jhala (2005); Sengupta (2003)). In the opinion of Bullis (1997); Sara Huhmann; Kazmi 2007), Srivastava, (2003), the rural area is a market where large portions of the population is illiterate. So when packing consumer products for rural markets, companies must use prominent symbols and colours to assure that illiterate consumers will be able to recognize the products Therefore, communicating brand values through the package rather than with words. Counterfeit Products are fakes that use the same name, design, colour scheme, trademark, logos and even same address and name of the manufacturers as that of original. Pass-off products are fakes that use similar sounding names with deceptively similar colour schemes and packing (Joppen 2005). Today the fake products under popular brand names constitute an almost parallel industry. Low brand awareness has a very negative impact on organized players. The unorganized players exploit this lacuna to push spurious products. Most of them give higher margins to the retailer, who is the most expensive and important link in the supply chain. HUL claimed that it was losing close to Rs. 1,600 crores (Sanjit Kundu 2000); (2004); (2005) every year in revenue to the counterfeit product makers while the Indian FMCG industry was suffering a loss of around Rs. 2,500 crore in revenue annually (2004) and the Government estimated to lose close to Rs 900 crore (2001); (2004) per annum in unpaid excise duty, sales tax and other levies. "Today the market is full of fake products ranging from salt and tea to high-end garments and shoes, no state has been spared" (Amit Mitra 2003). A study by the FICCI's Brand Protection Committee (BPC) has come out with the following findings - look-alike popular FMCG brands account for five to 15 per cent of the original brand sales volumes, with as many as 20 lakh dealers involved in the marketing of these products (Amit Mitra 2003).

\section{LITERATURE REVIEW}

The concept of rural marketing has been extensively investigated in the marketing literature. For example, the study of Indian villages began in the $18^{\text {th }}$ century with an intensive survey regarding the landholdings and later it was compared with various other villages in England (Cohn 1968). Later the study was focused towards rural economy Munro, Metcalfe (1832); Lipton, M. (1970); Upton, M (1967); Maine (1890). S.C. Dube's (1955) Indian Village, M.N. Srinivasan'(1955) India’s Villages, D.N. Majumdar's Rural Profiles, and McKim Marriott's Village India were all published in 1955. These studies covered a vast range of data and experience from different parts of India and most of these studies were single village studies. However, in the Indian marketing literature, a dominant theme is agricultural marketing focusing mainly on the marketing of agricultural produce and that of agricultural inputs. For example, Gaupule and Bhowmik (1983); Gupta (1975); Heredia (1978); Moore (1973); O'conner(1972). The major deficiencies drawn from the above empirical study are in terms of; (i) majority of rural population, the rural consumers being ignored (participants) and (ii) their consumption pattern has been ignored. Even in terms of products, the focus is limited to fine grains, cash crops and inputs like fertilizers, pesticides, seeds and farm machinery.

However, The concept of rural marketing has received a prominent attention in the literature with empirical studies being conducted on a wide array of activities such as rural consumers buying behaviour for example, Shivakumar (2002); Sehrawet (2007); Bose (1992); (MART) (2002); Velayudhan (1998); Rakesh Handa (1992); Das and Somnath (1991), counterfeit brands in rural marketing Gunjan Sharma Rana1 (2005);(Sathyanarayana 2014) role of opinion leaders inrural marketing (Kivlin, Roy P., and Sen (1968); Dube(1967); Dalviet al. (1968); David A. M., and others (1968) rural retailing practices (Sara Huhmann(2004) Lahiri; Bhandari and Iyer (1995); (Shivakumar \& Arun(2002)),supply chain management (Dawar and Chattopadhyay, (2002)); Ramaswamy and Namakuari; Gulati (2000)), Media habits of rural consumers (Purushotham Rao (1990); Sathyanarayana and B. H. Suresh (2017); (Dixit 2002); Suri \& Sudan (2003); Pareek (1999); Bhandari \& Iyer (1995); Branding Kaushik Mukerjee (2007)). Sales promotions (Joshi, 1991), Haats and melas (Pradep Kashyap; (Adite Chatterjee 1996); (Sathyanarayana and Suresh (2017)), ruralcommunications (Suresh \& Sathyanarayana (2008) and stores choice Sathyanarayana, S., \& Gargesha, S. (2017).

In the words of Vidya Hattangadi (2002); Kripalani, (2002) and (Dawar and Chattopadhyay, 2002), the package of a product plays the role of a silent salesman. Further they added that packaged products evoke a powerful mode to communicate. Packing plays a vital role in low income strata of a developing country like India especially in rural areas. These consumers have a limited strength of buying large quantity of products. Instead they prefer smaller quantities for their consumption for the sake of flexibility; in price, usage and experience. Emotional Surplus Identity (ESI)) is a concept that uses the shape, color, and content of a package to differentiate a brand in the eye of a consumer (Sen \& Jhala 2005); Sengupta (2003). In the opinion of Bullis (1997); Sara Huhmann; Kazmi(2007); (Srivastava, 2003), the rural area is a market where large portions of the population is illiterate. So when packing consumer products for rural markets, companies must use prominent symbols and colours to assure that illiterate consumers will be able to recognize the products Therefore, communicating brand values through the package rather than with words. 
The objective of the current paper is to identify, the behaviour of the rural consumers with respect to packing preference, viewing and reading habits and to offer suggestions to the marketers to frame better packing and pricing strategies to cater to the needs of the rural markets. The review of the literature on the proposed topic, thus throws light on facts relating to the gap in the study of the chosen subject. Most studies have been retrospective, and have neglected to collect the first hand information from rural respondents. The current study would make an addition to existing literature on rural marketing by collecting firsthand information from the rural respondents with respect to their FMCG packing reading habits. The structure of this empirical research paper is as follows. Section two outlines the review of previous literature. Section three describes the research design and the methodology of the current empirical study. Section four discusses the analysis and inference of the data collected and in thelast part a brief discussion have been made, conclusion have been drawn and the findings of the study are compared with the possible evidence.

\section{RESEARCH DESIGN}

\section{OBJECTIVES OF THE STUDY}

The aim of this exploratory study is to provide an in-depth organized understanding of the rural consumer in terms of packing preference, viewing and reading habits in the state of Karnataka, India, focusing on the aspects of rural marketing.

1. Influence of packing on rural consumer respondents while buying FMCG

2. Packing preference of the rural consumer respondents

3. Package reading habits of the rural consumer respondents and details observed in general by the rural consumer respondents on the FMCG wrapper while purchasing

4. Recognition of brands by the respondents

5. To offer suggestions to the marketers of FMCG based on this study.

\section{HYPOTHESIS OF THE STUDY}

H0: There is no significant influence of annual house hold income of the rural consumer respondents on the rate of importance of packing while buying FMCG.

H0: There is no significant influence of the annual house hold income of the rural consumers on kind of packing preference.

H0: There is no significant influence of the education on the package reading habits of the rural consumer respondents.

H0: There is no significant influence of the sex of the rural consumer respondents on the observed details on the FMCG wrapper.

H0: There is no significant influence of the sex of the rural consumer respondents on the means by which they recognize or identify a brand.

\section{RESEARCH METHODOLOGY}

\section{NATURE OF STUDY}

The study is exploratory in nature as it endeavors to uncover the latent behavioural aspects of rural consumers and retailers in the state of Karnataka.

\section{UNIVERSE OF STUDY AND POPULATION}

The universe of the study is rural retailers and consumers in the rural villages of Karnataka situated in India. The universe of the study is classified as North Karnataka, South Karnataka, East Karnataka and West Karnataka. The scope of the study is limited to rural consumer's packing viewing habits while buying FMCG. The study is based on the empirical survey of 200 villages situated in the state of Karnataka.

\section{PRIMARY DATA SOURCE}

Firsthand information was obtained from respondents through a structured questionnaire. An interview schedule was constructed to elicit information from the respondents. The researcher chose an interview schedule since the respondent has to be coaxed to answer the questions put forth in the questionnaire. Moreover the researcher had a stringent requirement for the data to be pure and in all senses comprehend the very spirit of the questionnaire and thus the research. The researcher could also clarify any doubts to the respondent and explain the objective of each question whenever the respondent raised doubts.

The questionnaire contained different sections and each section concentrated on particular aspect of the retailing and buying and consumer behavior. The questions were both open ended and close ended. In close ended, 
questions consisted of dichotomous, multiple choice and rating scales, to elicit the respondents' association with the question posed.

\section{PILOT STUDY}

Before scaling for full research, the researcher initiated a pilot study with 100 rural consumers. These collected questionnaires were analyzed to determine whether the data collected helps the researcher to fulfill the objectives of the study, apart from testing the validity of the questions put across to the respondents. The validity of the questionnaire was adjudged, using Cronbach's coefficient $(\alpha)$ was calculated to test the reliability and internal consistency of the responses. Cronbach's coefficient, having a value of more than 0.7 is considered adequate for such exploratory work. The values of $\alpha$ in this study for the reported questions were found to be $0.736,0.805,0.765$ etc. giving an average value of 0.794 . It implies that there is a high degree of internal consistency in the responses to the questionnaire.

\section{SAMPLE SIZE}

The researcher has arrived at a sample size of 1600 for rural consumer respondents from among four zones of Karnataka state comprising approximately 200 accessible villages.

\section{ANALYTICAL METHOD}

The data collected is initially organized in a meaningful manner with the help of software. Once organized, the researcher tabulated the frequencies, which provided the requisite profile of the data collected and helped the researcher build the contingency tables for further detailed analysis. On performing detailed analysis, patterns from the data is further put for validation through testing of hypothesis, wherever the researcher deemed important and based on the conditions set for such test.

\section{DATA ANALYSIS}

TABLE No. 4.1: INFLUENCE OF PACKING ON RURAL CONSUMER RESPONDENTS WHILE BUYING FMCG

\begin{tabular}{|l|r|r|}
\hline & Frequency & Percent \\
\hline Major & 400 & 25.0 \\
\hline Minor & 720 & 45.0 \\
\hline Not Much Significant & 280 & 17.5 \\
\hline Not at All & 200 & 12.5 \\
\hline Total & 1600 & 100.0 \\
\hline
\end{tabular}

Source: Field survey

\section{Inference:}

The intention of the researcher in constructing the Table 4.1 is to understand the importance of packing from the perception of rural consumer respondents. $45 \%$ of the rural consumer respondents state that packing is of a minor importance to them, followed by $25 \%$ indicating a contrasting reply as these rural consumer respondents feel that it is of major importance, $17.5 \%$ state that packing is not much significant and $12.5 \%$ or the rural consumer respondents indicate that it is not at all important.

\section{TABLE NO. 4.2: TEST OF SIGNIFICANCE: ANNUAL HOUSEHOLD INCOME OF THE RURAL CONSUMER RESPONDENTS ONINFLUENCE OF PACKING ON RURAL RESPONDENTS WHILE BUYING FMCG}

The intention of the researcher in constructing Table 4.2 is to understand the importance of packing when rural consumer shops for FMCG based on the annual house hold income of the rural respondents, to understand whether there exists a significant influence or not. To understand the above significance, the researcher constructed the following hypothesis and used a Pearson Chi-square statistic to prove or disprove the hypothesis.

H0: There is no significant influence of annual house hold income of the rural consumer respondents on the rate of importance of packing while buying FMCG. 
Pearson Chi-Square Tests

\begin{tabular}{|c|c|c|}
\hline & & $\begin{array}{l}\text { Rate the importance of packing } \\
\text { while buying FMCG }\end{array}$ \\
\hline \multirow[t]{3}{*}{ Annual House Hold Income } & Chi-square & 288.035 \\
\hline & df & 9 \\
\hline & Sig. & .000 \\
\hline
\end{tabular}

\section{Results:}

Since the tabulated value of $\chi^{2}$ is 288.035 with 9 degrees of freedom with a significance level of 0.000 which is lesser than the set significance of 0.05 (95\% confidence limit) for tabulated relationship. Therefore, we can reject the null hypothesis.

TABLE No. 4.3: PACKING PREFERENCE OF THE RURAL CONSUMER RESPONDENTS

\begin{tabular}{|c|c|c|c|c|c|c|}
\hline & \multicolumn{2}{|c|}{ Sachets } & \multicolumn{2}{|c|}{ Poly Pack } & \multicolumn{2}{|c|}{ Carton Pack } \\
\hline & $\mathbf{F}$ & $\%$ & $\mathbf{F}$ & $\%$ & $\mathbf{F}$ & $\%$ \\
\hline No & 24 & 1.5 & 840 & 52.5 & 13 & 84.5 \\
\hline Yes & 1576 & 98.5 & 760 & 47.5 & & 15.5 \\
\hline \multirow[t]{3}{*}{ Total } & 1600 & 100.0 & 1600 & 100.0 & & 100.0 \\
\hline & & \multicolumn{2}{|c|}{ Plastic jar } & \multicolumn{3}{|c|}{ Loose Pack } \\
\hline & & $\mathbf{F}$ & $\%$ & \multicolumn{2}{|c|}{$\mathbf{F}$} & $\%$ \\
\hline \multicolumn{2}{|l|}{$\mathrm{No}$} & 1200 & 75.0 & \multicolumn{2}{|r|}{48} & 3.0 \\
\hline \multicolumn{2}{|l|}{ Yes } & 400 & 25.0 & & 1552 & 97.0 \\
\hline Total & & 1600 & 100.0 & & 1600 & 100.0 \\
\hline
\end{tabular}

\section{Inference:}

Source: Field survey

The intention of the researcher is to understand the size of packing which is preferred by the rural consumer respondents, thus constructing Table 4.3 From Table 4.3, it is evident that $98.5 \%$ of the respondents preferred sachets, followed by $97 \%$ indicating loose packs, $47.5 \%$ indicating poly packs and $25 \%$ indicating plastic jars which are preferred size of packing among rural consumer respondents.

\section{TABLE No. 4.4: TEST OF SIGNIFICANCE: ANNUAL HOUSEHOLD INCOME ON RANKING THE PACKING PREFERENCE}

The intention of the researcher in constructing Table 4.4 is to understand the pattern of response for the kind of packing preference of the rural consumer respondents classified on the basis of annual house hold income of the rural consumer respondents. To understand the significance as to the influence of annual house hold income on kind of packing preference, the researcher constructed the following hypothesis and used Pearson chi-square test to prove or disprove the hypothesis.

H0: There is no significant influence of the annual house hold income of the rural consumers on kind of packing preference.

\section{Pearson Chi-Square Test}

\begin{tabular}{|l|l|r|}
\hline \multicolumn{2}{|l|}{} & \multicolumn{2}{|c|}{$\begin{array}{c}\text { Rating the kind of packing } \\
\text { preference }\end{array}$} \\
\hline Annual House Hold Income & Chi-square & 817.649 \\
\cline { 2 - 3 } & df & 15 \\
\cline { 2 - 3 } & Sig. & .000 \\
\hline
\end{tabular}

Results: Since the tabulated value of $\chi^{2}$ is 817.649 with 15 degrees of freedom with a significance level of 0.000 which is lesser than the set significance of 0.05 (95\% confidence limit) for tabulated relationship. Therefore, we can reject the null hypothesis. 
TABLE No. 4.5: PREFERENCE OF RURAL CONSUMER RESPONDENTS TO LOW UNIT PACKS

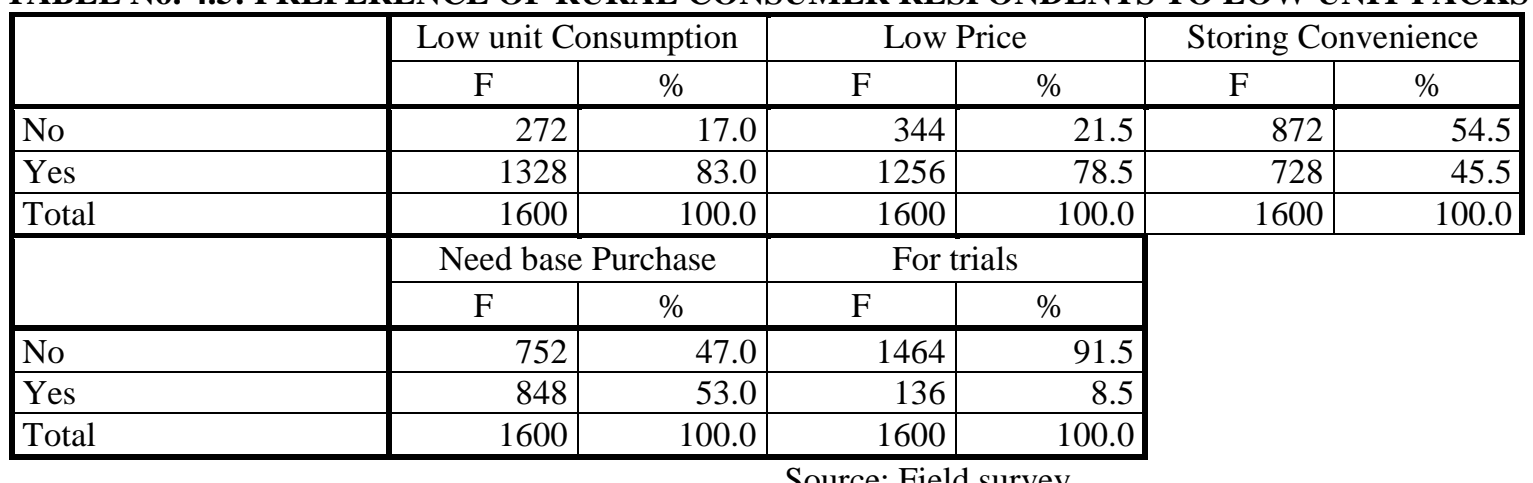

\section{Inference:}

The intention of the researcher in constructing Table 4.5 is to understand the reasons for preference of smaller packing size or sachets. From preliminary study the researcher has understood the following to be the reasons for preference, viz - low unit consumption, low price, storing convenience, need based purchase, and for trials. $83 \%$ of the rural consumer respondents indicate that low unit consumption as the prime reason, followed by $78.5 \%$ indicating low price, $53 \%$ indicating need based purchase and $45.5 \%$ indicating storing convenience.

TABLE No. 4.6: RATING THE PREFERENCE OF LOOSE PACKS BY THE RESPONDENTS

\begin{tabular}{|l|r|r|r|r|r|r|r|r|}
\hline \multirow{2}{*}{} & \multicolumn{2}{|c|}{ Flexible } & \multicolumn{2}{c|}{ Low Price } & \multicolumn{2}{c|}{$\begin{array}{c}\text { Low Quantity } \\
\text { Purchase }\end{array}$} & \multicolumn{2}{c|}{ Other Reasons } \\
\cline { 2 - 10 } & \multicolumn{1}{|c|}{ F } & \multicolumn{1}{c|}{ \% } & \multicolumn{1}{c|}{ F } & \multicolumn{1}{c|}{$\%$} & \multicolumn{1}{c|}{ F } & \multicolumn{1}{c|}{$\%$} & \multicolumn{1}{c|}{ F } & \% \\
\hline No & 472 & 29.5 & 368 & 23.0 & 640 & 40.0 & 1504 & 94.0 \\
\hline Yes & 1128 & 70.5 & 1232 & 77.0 & 960 & 60.0 & 96 & 6.0 \\
\hline Total & 1600 & 100.0 & 1600 & 100.0 & 1600 & 100.0 & 1600 & 100.0 \\
\hline
\end{tabular}

Inference:

Source: Field survey

The intention of the researcher in constructing Table 4.6 is to understand the reasons for rural consumer respondents preferring loose packs. $77 \%$ of the rural consumer respondents indicate the reason for preference is low price, $70.5 \%$ indicating flexibility and $60 \%$ indicating low quantity purchases.

TABLE No. 4.7:PACKAGE READING HABITS OF THE RURAL CONSUMER RESPONDENTS

\begin{tabular}{|l|r|r|}
\hline & Frequency & \multicolumn{1}{|c|}{ Percent } \\
\hline No & 568 & 35.5 \\
\hline Yes & 1032 & 64.5 \\
\hline Total & 1600 & 100.0 \\
\hline
\end{tabular}

Source: Field survey

Inference:

The intention of the researcher is to understand from the rural consumer respondents whether they observe packing of FMCG while they purchase. From Table 4.7 it is clearly evident that $64.5 \%$ of the rural consumer respondents indicate that they observe the packing and its written descriptions while purchasing FMCG and the rest $35.5 \%$ of the rural consumer respondents indicate that they do not observe the packing of FMCG while purchasing them.

\begin{tabular}{|c|c|c|c|c|c|c|c|c|}
\hline & \multicolumn{2}{|c|}{$\begin{array}{c}\text { Date of } \\
\text { Manufacturing } \\
\text { and Expiry }\end{array}$} & \multicolumn{2}{|c|}{ Brand Name } & \multicolumn{2}{|c|}{ Logos/ Signs } & \multicolumn{2}{|c|}{ MRP } \\
\hline & $\mathrm{F}$ & $\%$ & $\mathrm{~F}$ & $\%$ & $\mathrm{~F}$ & $\%$ & $\mathrm{~F}$ & $\%$ \\
\hline No & 280 & 17.5 & 512 & 32.0 & 528 & 33.0 & 160 & 10.0 \\
\hline Yes & 752 & 47.0 & 520 & 32.5 & 504 & 31.5 & 872 & 54.5 \\
\hline \multirow[t]{3}{*}{ Total } & 1032 & 64.5 & 1032 & 64.5 & 1032 & 64.5 & 1032 & 64.5 \\
\hline & \multicolumn{2}{|c|}{ Ingredients } & \multicolumn{2}{|c|}{ Special Offers } & \multicolumn{2}{|c|}{ Net Weight } & \multicolumn{2}{|c|}{ ISI Mark } \\
\hline & $\mathrm{F}$ & $\%$ & $\mathrm{~F}$ & $\%$ & $\mathrm{~F}$ & $\%$ & $\mathrm{~F}$ & $\%$ \\
\hline
\end{tabular}




\begin{tabular}{|l|r|r|r|r|r|r|r|r|}
\hline No & 848 & 53.0 & 544 & 34.0 & 816 & 51.0 & 808 & 50.5 \\
\hline Yes & 184 & 11.5 & 488 & 30.5 & 216 & 13.5 & 224 & 14.0 \\
\hline Total & 1032 & 64.5 & 1032 & 64.5 & 1032 & 64.5 & 1032 & 64.5 \\
\hline
\end{tabular}

\section{Inference:}

Source: Field survey

The intention of the researcher in constructing Table 4.8 is to understand what information the rural consumer observes on the FMCG packing while purchasing. 54.5\% of the respondents indicate that predominantly look for MRP, 47\% indicating they look for date of manufacturing and expiry, $32.5 \%$ indicating their search for brand name, $31.5 \%$ indicating their search and confirmation for logos and signs on the package of FMCG and $30.5 \%$ indicating that they look for special offers. Only 14\%, $13.5 \%$ and $11.5 \%$ indicate that they look for ISI mark, net weight and ingredients on the package of FMCG while purchasing them.

\section{TABLE No. 4.9: TEST OF SIGNIFICANCE: EDUCATION LEVEL OF THE RURAL RESPONDENTS ONOBSERVED DETAILS ON THE FMCG WRAPPER}

The intention of the researcher in constructing Table 4.9 is to understand the pattern of response for the kind of packing reading habits of the rural consumer respondents classified on the basis of education of the rural consumer respondents. To understand the significance as to the influence of education on packing reading habits, the researcher constructed the following hypothesis and used Pearson chi-square test to prove or disprove the hypothesis.

H0: There is no significant influence of the education on the package reading habits of the rural consumer respondents.

\section{Pearson Chi-Square Tests}

\begin{tabular}{|l|l|r|}
\hline \multicolumn{2}{|l|}{} & \multicolumn{1}{|c|}{$\begin{array}{c}\text { Observed details on the FMCG } \\
\text { wrapper }\end{array}$} \\
\hline Education Status & Chi-square & 598.281 \\
\cline { 2 - 3 } & df & 48 \\
\cline { 2 - 3 } & Sig. & .000 \\
\hline
\end{tabular}

Results: Since the tabulated value of $\chi^{2}$ is 598.281 with 48 degrees of freedom with a significance level of 0.000 which is lesser than the set significance of 0.05 (95\% confidence limit) for tabulated relationship. Therefore, we can reject the null hypothesis.

\section{TABLE No. 4.10: TEST OF SIGNIFICANCE: SEX OF THE RESPONDENTSON OBSERVED DETAILS ON THE FMCG WRAPPER}

The intention of the researcher in constructing Table 4.10 is to understand the pattern of response for the kind of packing reading habits (observed details on the FMCG wrapper) of the rural consumer respondents classified on the basis of sex of the rural consumer respondents. To understand the significance as to the influence of sex of the rural consumer respondents on packing reading habits, the researcher constructed the following hypothesis and used Pearson chi-square test to prove or disprove the hypothesis.

H0: There is no significant influence of the sex of the rural consumer respondents on the observed details on the FMCG wrapper.

\begin{tabular}{|c|c|c|c|c|c|c|c|c|c|}
\hline & & \multicolumn{8}{|c|}{ Observed details on the FMCG wrapper } \\
\hline & & \multicolumn{2}{|c|}{ Manf and Exp date } & \multicolumn{2}{|c|}{ Brand Name } & \multicolumn{2}{|c|}{ Logos/ Signs } & \multicolumn{2}{|l|}{ MRP } \\
\hline & & Count & Row \% & Count & Row \% & Count & Row \% & Count & Row \% \\
\hline \multirow[t]{3}{*}{ Sex } & Male & 520 & $71.4 \%$ & 384 & $52.7 \%$ & 344 & $47.3 \%$ & 592 & $81.3 \%$ \\
\hline & Female & 232 & $76.3 \%$ & 136 & $44.7 \%$ & 160 & $52.6 \%$ & 280 & $92.1 \%$ \\
\hline & Total & 752 & $72.9 \%$ & 520 & $50.4 \%$ & 504 & $48.8 \%$ & 872 & $84.5 \%$ \\
\hline & & \multicolumn{8}{|c|}{ Packing observation } \\
\hline & & \multicolumn{2}{|c|}{ Ingredients } & \multicolumn{2}{|c|}{ Special Offers } & \multicolumn{2}{|c|}{ Net Weight } & \multicolumn{2}{|l|}{ ISI Mark } \\
\hline & & Count & Row \% & Count & Row \% & Count & Row \% & Count & Row \% \\
\hline \multirow[t]{2}{*}{ Sex } & Male & 136 & $18.7 \%$ & 344 & $47.3 \%$ & 128 & $17.6 \%$ & 168 & $23.1 \%$ \\
\hline & Female & 48 & $15.8 \%$ & 144 & $47.4 \%$ & 88 & $28.9 \%$ & 56 & $18.4 \%$ \\
\hline
\end{tabular}




\begin{tabular}{|l|l|l|l|l|l|l|l|l|r|}
\hline & Total & 184 & $17.8 \%$ & 488 & $47.3 \%$ & 216 & $20.9 \%$ & 224 & $21.7 \%$ \\
\hline
\end{tabular}

Pearson Chi-Square Tests

\begin{tabular}{|l|l|r|}
\hline \multicolumn{2}{|l|}{} & \multicolumn{1}{|c|}{$\begin{array}{c}\text { Observed details on the FMCG } \\
\text { wrapper }\end{array}$} \\
\hline \multirow{2}{*}{ Sex of the Respondents } & Chi-square & 50.323 \\
\cline { 2 - 3 } & df & 8 \\
\cline { 2 - 3 } & Sig. & .000 \\
\hline
\end{tabular}

Since the tabulated value of $\chi^{2}$ is 50.323 with 8 degrees of freedom with a significance level of 0.000 which is lesser than the set significance of 0.05 (95\% confidence limit) for tabulated relationship. Therefore, we can reject the null hypothesis.

\section{Inference:}

From Table 4.10 it is evident to the researcher that $72.9 \%$ of the rural consumer respondents observe date of manufacturing and expiry on the packing, 50.4\% indicating the observation of brand name, $48.8 \%$ stating the observation on the pack being logos/signs, $84.5 \%$ indicating their observation being MRP on the package, $17.8 \%$ indicate that they observe the contents on the packing, $47.3 \%$ indicate that they search for special offers, $20.9 \%$ indicate their observation on the pack being net weight and $21.7 \%$ indicating their observation on packing being ISI mark. The male respondents observed on the packing for the MRP with $81.3 \%$ responses, $71.4 \%$ male respondents observing for date of manufacture and expiry, 52.7\% male respondents observing for brand name in packing and $47.3 \%$ observing for special offers on the package. The female rural consumer respondents observed on the packing for the MRP with $92.1 \%$ responses, $76.3 \%$ female respondents observing for date of manufacture and expiry, 52.6\% female respondents observing for logos/signs in packing, $44.7 \%$ female respondents indicate that they observe for brand name, $47.4 \%$ observing for special offers and $28.9 \%$ indicate that they observe for net weight on the package. Since the chi-square statistic has led to the rejection of null hypothesis, the researcher can safely infer that the patterns of response that arise on the kind of information the rural consumer respondents observe on packing based on the sex of the rural consumer respondents is significant and not random.

TABLE No. 4.11: RECOGNITION OF BRANDS BY THE RESPONDENTS

\begin{tabular}{|c|c|c|c|c|c|c|}
\hline & \multicolumn{2}{|c|}{ Reading } & \multicolumn{2}{|c|}{ By Colour } & \multicolumn{2}{|c|}{$\begin{array}{c}\text { Logos/ Picture/ } \\
\text { Trademark }\end{array}$} \\
\hline & $\mathrm{F}$ & $\%$ & $\mathrm{~F}$ & $\%$ & $\mathrm{~F}$ & $\%$ \\
\hline No & 544 & 34.0 & 784 & 49.0 & 832 & 52.0 \\
\hline Yes & 1056 & 66.0 & 816 & 51.0 & 768 & 48.0 \\
\hline \multirow[t]{3}{*}{ Total } & 1600 & 100.0 & 1600 & 100.0 & 1600 & 100.0 \\
\hline & \multicolumn{2}{|c|}{ Packing Style } & & & & \\
\hline & $\mathrm{F}$ & $\%$ & & & & \\
\hline No & 1160 & 72.5 & & & & \\
\hline Yes & 440 & 27.5 & & & & \\
\hline Total & 1600 & 100.0 & & & & \\
\hline
\end{tabular}

\section{Inference:}

The intention of the researcher in constructing Table 4.11 is to understand the how the rural consumer respondents recognize the brands, viz - through reading, by colour, logos/picture/trademark and by packing style. From Table 4.11, it is evident that $66 \%$ of the rural consumer respondents recognize brands through reading, 51\% recognizing through colours, 48\% through scanning of logos/pictures/trademark and $27.5 \%$ indicating that they recognize brands through packing style of the product.

\section{TABLE No. 4.12: TEST OF SIGNIFICANCE: SEX OF THE RESPONDENTSON BRAND RECOGNITION}

The intention of the researcher in constructing Table 4.12 is to understand the pattern of response for the means through which the rural consumer respondents recognized the brand of the product classified on the basis of sex of the rural consumer respondents. To understand the significance as to the influence of sex of the rural 
consumer respondents on means of recognizing the brand of the product, the researcher constructed the following hypothesis and used Pearson chi-square test to prove or disprove the hypothesis.

H0: There is no significant influence of the sex of the rural consumer respondents on the means by which they recognize or identify a brand.

\begin{tabular}{|c|c|c|c|c|c|}
\hline & \multicolumn{4}{|c|}{ Brand Recognition } \\
\hline & & \multicolumn{2}{|c|}{ Packing Style } & \multicolumn{2}{|c|}{ Other Identification } \\
\hline & & Count & Row \% & Count & Row $\%$ \\
\hline \multirow[t]{3}{*}{ Sex } & Male & 272 & $25.4 \%$ & 8 & $.7 \%$ \\
\hline & Female & 168 & $33.3 \%$ & 16 & $3.2 \%$ \\
\hline & Total & 440 & $27.9 \%$ & 24 & $1.5 \%$ \\
\hline
\end{tabular}

Pearson Chi-Square Tests

\begin{tabular}{|l|l|r|}
\hline \multicolumn{2}{|l|}{} & \multicolumn{1}{|c|}{ Brand Recognition } \\
\hline \multirow{2}{*}{ Sex of the Respondents } & Chi-square & 63.745 \\
\cline { 2 - 3 } & df & 5 \\
\cline { 2 - 3 } & Sig. & .000 \\
\hline
\end{tabular}

Results:

Since the tabulated value of $\chi^{2}$ is 63.745 with 5 degrees of freedom with a significance level of 0.000 which is lesser than the set significance of 0.05 (95\% confidence limit) for tabulated relationship.Therefore, we can reject the null hypothesis.

\section{CORRELATION ANALYSIS}

\section{TABLE No 4.13: RELATIONSHIP BETWEEN ANNUAL HOUSEHOLD INCOME AND THE PRACTICES OF OBSERVING GENERAL DETAILS ON PACKING AT THE POINT OF PURCHASE.}

The intention of the researcher is constructing Table No 4.13 is to understand the extent of correlation between the annual house hold income of the rural consumer respondents and the observation habits on the information available on product packing while purchasing from the retailer. To test for a liner relationship and its strength the researcher constructed the following hypothesis and used a Pearson correlation coefficient to prove or disprove the hypothesis.

H0: There is no significant correlation between annual household income of the rural consumer respondents and information observed on packing by the rural consumer respondents.

\begin{tabular}{|c|c|c|c|c|c|c|c|c|c|}
\hline & & \multicolumn{8}{|c|}{ Observe on Packing } \\
\hline & & $\begin{array}{c}\text { Date of } \\
\text { Manufact } \\
\text { uring and } \\
\text { Expiry }\end{array}$ & $\begin{array}{c}\text { For } \\
\text { Brand } \\
\text { Name }\end{array}$ & $\begin{array}{l}\text { Logos/ } \\
\text { Signs }\end{array}$ & MRP & $\begin{array}{l}\text { Ingredie } \\
\text { nts }\end{array}$ & $\begin{array}{l}\text { Special } \\
\text { Offers }\end{array}$ & $\begin{array}{c}\text { Net } \\
\text { Weight }\end{array}$ & $\begin{array}{c}\text { ISI } \\
\text { Mark }\end{array}$ \\
\hline \multirow[t]{3}{*}{$\begin{array}{l}\text { Annual } \\
\text { House Hold } \\
\text { Income }\end{array}$} & $\begin{array}{l}\text { Pearson } \\
\text { Correlation }\end{array}$ & $.066(*)$ & $.091(* *)$ & $-.241(* *)$ & $\begin{array}{r}- \\
.123(* \\
*)\end{array}$ & $.142(* *)$ & $.087(* *)$ & $.063(*)$ & -.021 \\
\hline & Sig. (2-tailed) & .034 & .003 & .000 & .000 & .000 & .005 & .043 & .502 \\
\hline & $\mathrm{N}$ & 1032 & 1032 & 1032 & 1032 & 1032 & 1032 & 1032 & 1032 \\
\hline
\end{tabular}

Result: As the tabulated value of Pearson correlation coefficient for observation of date of manufacturing is 0.66 , with a significance level of $0.34 ; 0.091$ for observation for brand name on packing with a significance level of $0.003 ;-0.241$ for observation of logos and signs with a significance level of 0.000 ; -0.123 for observation of MRP with a significance level of $0.000 ; 0.142$ for observation of packing ingredients with a significance level of $0.000 ; 0.087$ for observation of special offers on packing with a significance level of 0.005 ; and -0.063 for observation of net weight on the package with a significance level of 0.043 , all of these having a significance values less than 0.05 , the null hypothesis is rejected and the alternative accepted. In case of 
observation of ISI mark, with a Pearson correlation value of -0.021 , with a significance level of 0.502 , which is greater than the set significance of 0.05 , the null hypothesis is accepted and the alternative rejected.

Accepted Hypothesis: (H1) - There is a significant correlation between annual household income of the rural consumer respondents and observation of date of manufacturing, brand name, logos and signs, MRP, ingredients, special offers and net weight on the packing by the rural consumer respondents while purchasing. Accepted Hypothesis: (H0) - There is no significant correlation between annual household income of the rural consumer respondents and observation of ISI mark by the rural consumer respondents while purchasing.

\section{Inference:}

From Table No: 4.13 the intention of the researcher is to understand the extent of correlation between the annual household income on the observation of various pertinent information on packing like - date of manufacturing and expiry, brand name, logos and signs, MRP, Ingredients, special offers, net weight and ISI mark. From Table No: 4.13 it is clearly evident to the researcher that there is a very low positive correlations between annual house hold income and observation of date of manufacturing and expiry with a Pearson correlation coefficient of 0.066, observation of brand name with a Pearson correlation coefficient of 0.091 , observation of special offers with a Pearson correlation coefficient of 0.087 . There is also a low positive correlation of observation of packing ingredients with annual household income with a Pearson correlation coefficient of 0.142 and low negative correlation of logos and signs with a Pearson correlation coefficient of -0.241 and observation of MRP with a Pearson correlation coefficient of -0.123 . There is also a very low negative correlation of observation of net weight with a Pearson correlation coefficient of -0.63 and observation of packing with a Pearson correlation coefficient of -0.021 . From Table No:4.13, it is clearly evident that the there is no strong positive or negative correlation that is arising between annual household income and observation of pertinent variables on the packing. As the Pearson correlation is significant at 0.05 for the following observations on packing - viz, date of manufacturing and expiry, brand name, logos and signs, MRP, Ingredients, special offers and net weight, the researcher can safely infer that there is a significant correlation that exist between the annual household income and the observation of above pertinent variables on the package by the rural consumer respondents.

\section{TABLE No 4.14: RELATIONSHIPBETWEEN ANNUAL HOUSEHOLD INCOMES AND BRAND RECOGNITION HABITS.}

The intention of the researcher is constructing Table No: 4.14 is to understand the extent of correlation between the annual house hold income of the rural consumer respondents and the means used by the rural consumer respondents in recognizing a brand. To test for a liner relationship and its strength the researcher constructed the following hypothesis and used a Pearson correlation coefficient to prove of disprove the hypothesis.

H0: There is no significant correlation between annual household income of the rural consumer respondents and means by which the rural consumer respondents recognize a brand.

Correlations

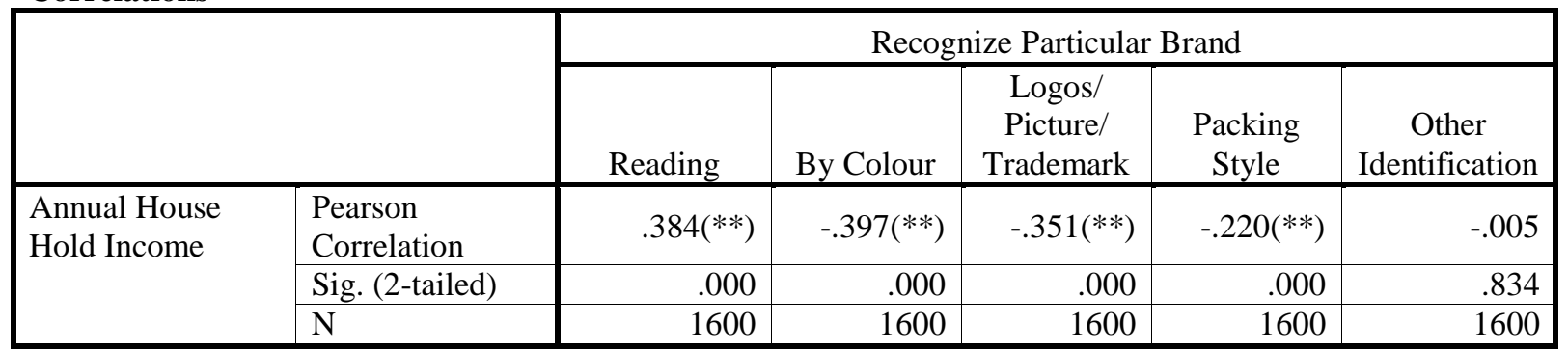

** Correlation is significant at the 0.01 level (2-tailed).

\section{Result:}

As the tabulated value of Pearson correlation coefficient for recognizing the brand through reading is 0.384 , with a significance level of $0.000 ;-0.397$ for recognition of brand by colour with a significance level of 0.000 ; 0.351 for recognizing brands through logos and signs with a significance level of $0.000 ;-0.220$ for recognizing brands through packing style with a significance level of 0.000 , all of these having a significance values less than 0.05 , the null hypothesis is rejected and the alternative accepted. In case of recognition of brands through other identification techniques, with a Pearson correlation value of -0.005 , with a significance level of 0.834 , which is greater than the set significance of 0.05 , the null hypothesis is accepted and the alternative rejected. 
Accepted Hypothesis: (H1) - There is a significant correlation between annual household income of the rural consumer respondents and recognition of brand through reading, colours, logos, pictures and trademarks, and packing style by the rural consumer respondents while purchasing.

Accepted Hypothesis: (H0) - There is no significant correlation between annual household income of the rural consumer respondents and recognition of a brand through other identification means by the rural consumer respondents while purchasing.

\section{Inference:}

From Table No: 4.14the intention of the researcher is to understand the significance of correlation between annual household income and recognition of brands through- reading, colours, logos, pictures and trademarks, packing style and other identification techniques. From Table No: 4.14it is evident to the researcher that there is a moderate negative correlations between annual house hold income and recognizing a brand through colour with a Pearson correlation coefficient of -0.397 , recognizing a brand through logos, picture and trademark with a Pearson correlation coefficient of -0.351 and recognizing a brand through packing style with a Pearson correlation coefficient of -0.220 . There is an observable very low negative correlation between annual household income and recognizing a brand through other identification means with a Pearson correlation coefficient of -0.005 . There is a moderate positive correlation between annual household income and recognition of brand through reading with a Pearson correlation coefficient of 0.384 . As the tabulated significance has lead to the rejection of null hypothesis the researcher can safely infer that there is a significant correlation between annual household income and recognition of brand through reading, colours, logos, pictures and trademarks, and packing style.

\section{DISCUSSION AND CONCLUSION}

The current study has been undertaken with an intention to understand the role of packing while buying FMCG. In order to realize the stated objectives the researcher constructed a structured questionnaire has been constructed and pre tested and administered on 1,600 rural respondents spread across 200 villages in the state of Karnataka. The validity of the questionnaire was adjudged, using Cronbach's coefficient $(\alpha)$ was calculated to test the reliability and internal consistency of the responses. Following were the major findings of the study $45 \%$ of the rural consumer respondents attributed minor importance to packing, 25\% attributing a major importance, $17.5 \%$ attributing not much significant and $12.5 \%$ attributing packing as not at all important. There is a significant difference in the opinion of rural consumer respondents on importance attributed to packing while purchasing FMCG as perceived by rural consumer respondents. There is a significant influence of annual house hold income of the rural consumer respondents on the level of importance attributed to packing while buying FMCG.98.5\% of the rural consumer respondents preferred sachets, $97 \%$ preferred loose packs, $47.5 \%$ preferred poly packs and $25 \%$ preferred plastic jars. There is a significant difference in the packing size preference of the rural consumer respondents while purchasing products. There is a significant influence of the annual house hold income of the rural consumers on kind of packing preference. $83 \%$ of the rural consumer respondents prefer sachets of their low unit consumption as the prime reason, $78.5 \%$ stating low price, $53 \%$ stating need based purchase and $45.5 \%$ stating storing convenience. There is a significant difference in the reasons articulated by the rural consumer respondents for the preference of low unit packs or sachets.77\% of the rural consumer respondent state the reason for preference is low price, $70.5 \%$ state flexibility and $60 \%$ state low quantity purchases. There is a significant difference in the reasons articulated by the rural consumer for the preference of loose packs.64.5\% of the rural consumer respondents observe the written descriptions while purchasing FMCG and $35.5 \%$ do not observe the packing of FMCG while purchasing.54.5\% of the rural consumer respondents look for MRP, 47\% look for date of manufacturing and expiry, 32.5\% look for brand name, 31.5\% look for logos and signs and $30.5 \%$ look for special offers. There is a significant influence of the education on the packing reading habits of the rural consumer respondents. There is a significant influence of the sex of the rural consumer respondents on the packing reading habits.66\% of the rural consumer respondents recognize brands through reading, $51 \%$ recognize through colours, $48 \%$ through scanning of logos/pictures/trademarks and $27.5 \%$ recognize brands through packing style of the products. There is a significant difference in the means used by the rural consumer respondents for recognition of a brand. There is a significant influence of the sex of the rural consumer respondents on the means by which they recognize or identify a brand.54\% of the rural consumer respondents are never induced by the special gifts, offers or discounts; $18.5 \%$ are rarely induced by gifts, special offers or discounts and $16 \%$ are influenced by special offers, discounts and gifts some times. $37.5 \%$ of the rural consumer respondents will try new brands if they are provided with gifts, offers or special discounts and $62.5 \%$ are loyal to the existing brands.57.5\% of the rural consumer respondents indicate that they sometimes switch brands, $40.5 \%$ never switch brands and $1 \%$ each articulates that they mostly and, always switch brands. There is a significant difference in the rate at which the rural consumer switches brands. $49.5 \%$ of the rural consumer 
respondents state that the factors that influence to switch brands is special offers, $41 \%$ indicating the nonavailability of current brand, $21 \%$ indicating price reduction, $20 \%$ switching for good quality and $10.5 \%$ switching by just impulse. There is a moderate negative correlation between logos/ signs observed on the packing -.241 and marginal positive correlation of .142 for observing the ingredients on packing associated with annual house hold income of the respondents. There exists a moderate negative correlation for the identification of brands through colours with -.397, -.351 using logos, pictures and trademarks and -.220 for packing style and a moderate positive correlation for reading as the means of recognizing a particular brand with 0.384 when associated with the annual house hold income of the respondent.

As per rural retailers and consumers, the most preferred packing size while purchasing FMCG is sachets and loose packs. Major reasons for preference of loose packs are storing convenience, low unit consumption, low price, need based purchase and flexibility. Through low unit packs, the marketers can also reach daily wage earners, as it provides them an opportunity to purchase some minimum quantity of product at lesser amount of money. Even retailers felt sachets are very important because of fast moving nature, storage convenience; need based purchase and trial purchase by the respondents. Therefore, it is suggested that the marketers offer products in flexible and low unit packs. Even while designing the packages, local language should be used. Colours should be used extensively and distinctive. Date of expiry or manufacture and MRP should be displayed in bold letters (because these are the most observed contents on packs in rural areas). This ensures that over pricing of products by rural retailers is minimized. Evidence from this study shows that a majority of rural consumers even now ask for just about any brand while buying FMCG, this is one of the important factors for pass-off, spurious or counterfeit and regional brands' push by the retailers. As rural consumers recognize brands by packing , logos, trademarks and colours, a few unscrupulous marketers introduce pass off or look alike spurious products to exploit the rural consumer's emotional surplus identity. In most cases, spurious products are pushed by the multi brand wholesalers in the feeder towns and district headquarters because of the huge margin involved in this parallel channel. They act either as merchant middle men or manufacturers of spurious products or the manufacturing of these products are outsourced. This issue is very important from their perspective, because of the big margin involved in the sale of spurious products. Therefore, in this regard, it is suggested to employ the product's name in local languages and dialects to create consumer awareness.

For rural products, the strategies adopted must focus on cutting the middlemen margins; reducing frills and keeping lower stocks to reduce transaction costs and passing these benefits to customers can further increase the turnover. Therefore, it is suggested that marketers use urban markets for value and rural markets for volume to achieve trade-off between value and volume. Alternative to this "direct consumer" strategy, traveling "sales force" can also be incorporated to pass the benefits to the consumers. Keeping in view the seasonality and low disposable income of the rural consumers, penetration pricing will undoubtedly be very effective.

\section{LIMITATIONS OF THE STUDY AND SCOPE FOR FURTHER RESEARCH}

In the background of the current empirical research, the researchers have identified the following areas for future research which can be carried in the field of rural marketing to enrich the rural literature. First, the current study was conducted only on a sample size of 1,600 rural consumer respondents and was confined to geographical limits of Karnataka state only, therefore, the results obtained may not be pertinent to the country as a whole. Therefore, it is recommended to conduct an extended study of this kind encompassing more number of states or geographies (to capture to cultural differences across regions) and larger sample size may be taken up. The present study on rural markets has been restricted to FMCG sector only. A study covering both consumer products and durables may be taken up. Furthermore, research can be carried out about the role opinion leaders in the rural marketing. More empirical studies would be needed for generalizing the findings of the study at the micro and macro level.

\section{REFERENCE}

1. Adapted from Traditional Haats and Melas in India, a research report by Pradeep Kashyap, sponsored by the Ministry of Rural Areas and Employment, Government of India.

2. Adite Chatterjee. (1996), "Haats and Melas", Business Today, October 7-21, pp. 125-133.

3. Amit Mitra. (2003), "Fakes of big FMCG brands make fast buck: Study", The Business Line (Financial Daily from THE HINDU group of publications), Wednesday, August 06.

4. Bose D. K. (1992), "Reaching out to the rural millions", The Economic Times, Brand Equity, 28th December..

5. Bullis, D., Selling to India's consumer market. Westport, CT: Quorum Books. 1997.

6. D.N. Majumdar (ed.) (1955) "Rural Profiles", Luknow: Ethonographic and Folkculture Society. 
7. Dalvi A. N. and others (1968). "Opinion Leaders in a small community” unpublished study by IIMA, May.

8. Dawar, N. \&Chattopadhyay, A. (2002), "Rethinking marketing programs for emerging markets", Long Range Planning, 35, pp. 457.

9. Dube S. C. (1967), "Communication, Innovation and planned change in India" in Learner Daniel and Schramm (eds.), "Communication and Change in developing countries" (East West Centre Press Honolulu.

10. Dube, S.C. (1958), "India's changing villages", Routledge and Kegan Paul, Ltd., London.

11. Fliegel F. C., Roy P., Sen L. K. (1968), “Agricultural innovations in Indian Villages” (March 1968) and Agricultural Innovations among Indian farmers, Hyderabad, National Institute of Community Development, May.

12. Francis Xavier. (2001), "Marketing to rural India", The Hindu Business Line Catalyst, Thursday, October 11.

13. Gaupale, S P, Sane, S N and Bhowmik. (1983), M "Evaluation of Sales Promotional Mix Adopted by Different Pharmaceutical Companies for their Veterinary Products," Indian Journal of Marketing, 13, 5, pp. 6-8.

14. Gunjan Sharma Ranal. (2005), "Counterfeit Defeat Brands" Rai University - Business School, April 2005 Working Paper Series. Social Science Research Network, April.

15. Gupta, A P. (1975), "Marketing of Agricultural Produce in India", Bombay: Vora and Co.

16. Heredia, F J. (1978), "System Approach to Fertiliser Marketing," Fertiliser News, July, pp. 3-6.

17. JesalThakker and KapilBhagag. (2000). "Rural Markets - Mirage or Reality", October 11, 2000, contributed by Students of NarseeMonjee Institute of Management Studies http.www.Indiainfoline.com.

18. Joshi, A. (1991), "Rural marketing: The new El-Dorado", The Sunday Observer, April 28 -May 4.

19. K. Shivakumar and G. Arun. (2002), "Buying behaviour in the Hinterland", Indian Management, Theme: The rural consumer, Vol 41, issue 7, October, pp. 55 - 57.

20. Kivlin J. E., Roy P., Fliegel F. C., Sen L. K. (1968), "Communication in India" NICD - Hyderabad May.

21. Kripalani, M. (2002), "Rural India, have a Coke". Business Week, 24

22. Lipton, M. (1970), "Interdisciplinary Studies in Less Developed Countries", Joint Reprint Series No.35. Institute of Development Studies, University of Sussex, Brighton.

23. Lucien Joppen . (2005), "food safety Damage through fake food - Industry sits on its hands", Food Engineering \& Ingredients, 12 April, pp. 12-14.

24. M. N.Srinivas ., (ed.) (1955), "India's Villages”, Calcutta: Government of West Bengal Publications.

25. Maine, Sir Henry. (1890), "Village Communities in the East and West", New Edition, John Murray, London.

26. McKim Marriott (ed), (1955)"Village India”, Chicago: Chicago University Press.

27. Metcalfe, Sir Charles. (1832), Report of the Select Committee of the House of Commons, Vol. III, Appendix 84, p.331, cited in Srinivas, M.F., (Ed.). India's Villages.

28. MinoutiKamat and R. Krishnamoorthy. (2003), "Rural Marketing", Himalaya publishing House, Mumbai, pp. 4-5.

29. Moore, John R, et al. (1973), Indian Food Grain Marketing, New Delhi: Prentice-Hall.

30. Mukunda Das V, Somanath Sen. (1991), "Missing the point" -the rural way, A\&M, July, pp. 22.

31. O’Connor, James J. (1972), "Food Marketing - Systems Approach to Human Concern”, in New Perspectives in Marketing, New Delhi, NCAER, pp. 134-139.

32. Pawan Bhandari, RajatIyer. (1995), "Getting your message across", A\&M, 15 February 1995; pp. 2728.

33. Pawan Bhandari, RajatIyer. (1995), "Siphoning a deal”, A\&M, 15 January; pp. 23-26.

34. Preeti Mehra. (2002), "How to 'woo' the rural woman”, The Hindu Business Line, Marketing - Rural Marketing, Tuesday, July 23.

35. Purushotham Rao P. (1990), "Rural Urban and Socio-Economic Variations in consumer Behaviour", Unpublished thesis, Osmania University.

36. Rakesh Handa., "Rural Marketing Strategies in India", Indian Journal of Marketing, pp. 29.

37. Richa Mishra. (2003), "LG bets on economy range, infrastructure to tap rural market", The Hindu Business Line, Marketing - Rural Marketing, Saturday, October 04.

38. Rohini Gupta Suri, Dr. Amrik Singh Sudan. (2003), "Rural Marketing - some issues", Indian Journal of Marketing, Vol. XXXIII; No. 10, October.

39. Sampa Chakrabarty Lahiri. (2000), "Strategic Issues -A Peek into the rural market", www.etstrategicmarketing.com/smJune-July2/art6_1.htm - 63k - Cached - Similar pages

40. Sanjit Kundu. (2000), "Business: Counterfeit”, Business World, 27 November. pp. 70-72. 
41. Sathyanarayana S and Ramani Ganesh. (2008), "Rural Retail Management", Journal of Contemporary Research in Management, July - Sep pp. 81-99

42. Sathyanarayana S. (2011). "Trends in the marketing of FMCGs in Karnataka state", Dharana Bhavan's International Journal of Business. Vol. 5, 1\&2 (Jan-June). ISSN 09740-0082, pp. 61-73

43. Sathyanarayana S. (2014). "The role of spurious products in rural retailing-A study", Dharana Bhavan's International Journal of Business. Vol. 8, No. 1 (Jan-June). ISSN 09740-0082, pp. 11-21.

44. Sathyanarayana, S., \& Gargesha, S. (2017). Determinants of Stores Choice in Rural Markets: An Empirical Study in Karnataka State. IRA-International Journal of Management \& Social Sciences (ISSN 2455-2267), 6(2), 235-252.

45. Sathyanarayana, S and Suresh B. H. (2017), "Reaching Out To the Rural Consumers through Haats: A Study in Karnataka". International Journal of Business and Management Invention. Volume 6, Issue 1, January, pp. 55-64.

46. Sathyanarayana, S and Suresh B. H. (2017), "Targeting the non-urban consumers: media habitsand preference of rural consumers in Karnataka state". International Journal of Retailing \& Rural Business Perspectives. Volume 6, Number 1, January - March' 2017. ISSN (Print): 2279-0934, (Online): 22790942

47. Sehrawet, Mahavir; Kundu, Subhash C. (2007), "Buying behaviour of rural and urban consumers in India: the impact of packing ", International Journal of Consumer Studies, Volume 31, Number 6, November , pp. 630-638(9).

48. SHH Kazmi. (2002), "Marketing management text and cases”, Excel books, New Delhi, pp. 624.

49. Shombit Sen\& Renee Jhala. (2005), "What's behind Wipro's 'flower' logo", August 05, http://www.rediff.com///money/2005/aug/05bspec.htm date of download 21-06-2016.

50. Shombit Sengupta. (2003), "Fil Conductors Creates Emotional Surplus", Strategic Marketing, JulyAugust.

51. Srivastava, Prashant. (2003), "Personal Communication", October 21 and October 31.

52. Sumita Vaid Dixit. (2002), "Media is most effective in rural India, says MART study", www.agencyfaqs.com, NEW DELHI, October 10.

53. Suresh B. H., and Sathyanarayana S. (2008), "Rural communications", Journal of Contemporary Research in Management, July - Sep pp. 29-42

54. Title Saket Gulati. (2000), "Rural marketing opportunities in Rajasthan" Unpublished thesis, under the guidance of Mr. Anil Sharma and Mr. R. S. Lamba. IIMB - Library MD/ NBM Section E17832.

55. Upton, M., (1967) "Agriculture in South-Western Nigeria", Department of Agricultural Economics Development Study, No.3, University of Reading, Reading.

56. Velayudhan, Sanal Kumar. (1998), "Buyer behaviour in rural markets: A study of soap market", productivity, Vol. 39, No. 2. July-September.

57. Vidy aHattangadi and her team. (2000), "Case Study Braving the Bharat Bazar", SIES Journal of Management, 17 April-September, pp. 16-19.

58. Vivek Pareek. (1999), “Animating the Message”, A\&M, 15 September, pp. 95.

59. $22,2001$. 60. "HLL seeks state help to tackle counterfeiting", The Hindu Business Line, December 22, 2004 "FMCG industry's initiative to protect brands", The Hindu, Thursday, February , "Industry Associations Machinery for counterfeit FMCG items seized", The Hindu Business Line, Home Page - Personal Products, Marketing -Piracy, Industry \& Economy Wednesday, August 18, 2004. "Machinery for counterfeit FMCG items seized", Industry \& Economy - Industry Associations, The Hindu Business Line, Wednesday, August 18, 2004.

63. , "Price cuts revive FMCG sector fortunes', The Hindu, Sunday, January 02, 2005.

64. _— "Offer products to suit rural markets", The Hindu, Saturday, October 06, 2001.

65. "Rural markets: Long haul, but big opportunities", India Post News Service, http://www.indiapost.com/new_ip/members/story.php?story_id=1273, Published on 27-08-2002, Date of download 8-03-2016. 